\title{
Beyond ritual and economics: Maasai lion hunting and conservation politics
}

\author{
Mara J. Goldman, Johna Roque de Pinho and Jennifer Perry
}

\begin{abstract}
Populations of the African lion Panthera leo are declining dramatically, with the species' survival in some areas closely linked to levels of tolerance by rural communities. In Tanzania and Kenya several of the remaining lion populations outside protected areas reside adjacent to rural communities, where they are hunted. As many of these communities are Maasai, research and conservation efforts have focused on understanding and curbing Maasai lion hunting practices. Much of this work has been informed by a dichotomous explanatory model of Maasai lion hunting as either a 'cultural' ritual or a 'retaliatory' behaviour against predation on livestock. We present qualitative data from interviews $(n=246)$ in both countries to illustrate that lion hunting by Maasai is related to overlapping motivations that are simultaneously social, emotional and political (in response to conservation initiatives). Additional case study material from Tanzania highlights how politics associated with conservation activities and age-set dynamics affect lion hunting in complex and overlapping ways. Our findings contribute an ethnographic perspective on Maasai lion hunting, people-predator relations, and how these relations are linked to conservation politics.
\end{abstract}

Keywords Conservation politics, ethnography, Kenya, lion, Maasai, Panthera leo, Tanzania

\section{Introduction}

$\mathrm{M}$ any populations of lion Panthera leo are decreasing, and the species is categorized as Vulnerable on the IUCN Red List (Bauer et al., 2008). Although most lions occur within protected areas (Frank \& Packer, 2003) they also migrate beyond park boundaries at different times of the year in search of prey. Once outside protected areas lions come into contact with human populations, where they can

MARA J. Goldman (Corresponding author) Department of Geography, Environment and Society Program, Institute for Behavioral Science, University of Colorado at Boulder, Guggenheim 110, 260 UCB, Boulder, Colorado 80309-0260, USA. E-mail Mara.goldman@colorado.edu

JoAna Roque De Pinho Centro de Administração e Políticas Públicas, Instituto Superior de Ciências Sociais e Políticas, Universidade Tecnica de Lisboa, Lisbon, Portugal, and Natural Resource Ecology Laboratory, Colorado State University, Fort Collins, Colorado, USA

JENNIFER PERRY Department of Geography, University of Colorado at Boulder, Boulder, Colorado, USA

Received 31 October 2011. Revision requested 10 February 2012.

Accepted 11 June 2012. First published online 14 May 2013. inflict great costs through livestock depredation and human casualties, while running the risk of being killed by people (Frank et al., 2006). With a view to protect lions conservation projects have been developed outside protected areas. Such efforts often include social science analyses of how people interact with lions and proposals to improve tolerance of the predators (Romañach et al., 2007; Hazzah et al., 2009; Maclennan et al., 2009). Ogada et al. (2003: 1,522) argue that a high proportion of carnivore deaths occur as a result of deliberate killings by 'people who perceive large carnivores as a threat to livestock.' Lions are not the most damaging predators in terms of actual depredation costs (Patterson et al., 2004; Holmern et al., 2007) but are a visible threat that herders try to manage, and are often the most feared of all predators (Roque de Pinho, 2009).

In Tanzania lion hunting is legal outside national parks if a sports hunting permit is issued by the Director of Wildlife for a specific location. All other instances of lion hunting are illegal (URT, 2009). The Wildlife Act (URT, 1974, 2009) allows traditional groups to obtain hunting rights, and for game scouts to kill so-called problem animals with the approval of the game department at the district level. In Kenya all hunting, including of lions, was banned in 1977 (Steinhart, 1989). However, the killing of lions is legal if the perpetrator can prove that it was in defence of life or property, including livestock' (Maclennan et al., 2009: 2,425; citing the Wildlife Act, 1989). Maasai hunting of lions in both countries usually occurs without following procedures outlined in the law and seems to be tolerated by the authorities. In practice prosecution is rare, probably because of the group effort of the hunt, which makes responsible individuals difficult to isolate.

Although researchers in Kenya claim that Maasai hunting of lions is threatening the population with extinction (Hazzah et al., 2009), in Tanzania research suggests that unsustainable sport hunting is the greatest threat to the lion population (Lichtenfeld, 2005; Packer et al., 2010). Nonetheless, researchers in both countries stress the need to understand Maasai lion hunting better as a part of the long-term conservation of the species (Ikanda \& Packer, 2008; Kissui, 2008; Hazzah et al., 2009). Maasai areas have some of the largest concentrations of wildlife, with many national parks adjacent to Maasai areas (Homewood \& Rodgers, 1991). For this reason Maasai are often the target of wildlife conservation interventions. Maasai also hold a special place in the international imagination, being seen as intimately connected to ideas of wild Africa 
(Bruner \& Kirshenblatt-Gimblett, 1994). Tourists come to Tanzania and Kenya on wildlife safaris with an expectation to see Maasai as a part of their tour. Maasai have been romanticized as both a part of nature and a relic of tribal Africa. It is within such a context that Maasai lion hunting is often depicted, as a romantic remnant of a tribal past. Yet today, with lion populations threatened globally, Maasai lion hunting is drawing outrage; misunderstood and shocking to Western sensitivities, concerns have been raised in the media and conservation literature (Crilly, 2006; Frank, 2006; Frank et al., 2006; Roach, 2006; Maclennan, 2007).

In the human-wildlife conflict literature hunting of predators by local communities is often classified as 'retaliatory' and 'non-retaliatory' (Woodroffe et al., 2005). The same is true for much of the literature on Maasai lion hunting, with 'non-retaliatory' hunts categorized as 'cultural'. We suggest that such a classification is unhelpful and, moreover, stems from an incomplete understanding of Maasai language and culture by assuming the existence of two separate types of lion hunts: a cultural/manhood ritual, referred to as olamayio, and a retaliatory hunt, labelled olkiyioi (Hazzah, 2006; Ikanda \& Packer, 2008; Hazzah et al., 2009). This typology leads to a certain set of solutions for curbing Maasai hunting of lions: change cultural practices and/or address lion predation on livestock through compensation programmes and improved husbandry (Ogada et al., 2003; Frank, 2006; Maclennan et al., 2009). We suggest that this dichotomous explanation is limited in both analytical power and in its usefulness to inform lion conservation strategies. By labelling practices as either 'cultural' and in need of change, or as linked to Western concepts of value and exchange, and paid for accordingly, Maasai understandings of lions, human-lion interactions, and conservation are not recognized. This could have detrimental effects for the success of conservation (Goldman et al., 2010) and contradicts recent proposals in the literature for participatory approaches to human-wildlife conflict (Treves et al., 2006, 2009).

Here we draw on in-depth ethnographic engagements with Maasai communities in Kenya and Tanzania to propose an analytical framework of Maasai lion hunting practices based on Maasai knowledge and understanding. We present lion hunting as related to multiple and overlapping causes, reflecting social, emotional and political motivations. The political aspect of lion hunting by Maasai has been noticeably absent from recent scientific literature and conservation reports, despite earlier accounts of politically motivated hunting in the area (Western, 1982) and the political nature of human-wildlife conflict in general (Treves \& Karanth, 2003; Treves et al., 2006).

In an attempt to build a more complete, culturally appropriate perspective on Maasai lion hunting we present qualitative and ethnographic data related to two questions: (1) Why do Maasai hunt lions? (2) How are Maasai lion hunting patterns related to conservation politics (understood as the uneven power dynamics related to land use and conservation decision-making)? Answering the first question is essential to ensure conservation interventions targeting communities are appropriate and effective. It is addressed through data collected at both sites. The second question highlights the challenges surrounding conservation interventions in community lands through a case study from the Tanzania site, supplemented with additional material on similar cases in Kenya.

\section{Maasai and lion hunting}

We draw on our own ethnographic data and prior research to explain specific aspects of Maasai social structure and lion hunting practices for both study sites. Maasai are a predominantly pastoralist people who inhabit the savannah grasslands of southern Kenya and northern Tanzania. They are divided into territorial sections, and linked through clan affiliations and a common age-grade/age-set system (Spear \& Waller, 1993). Our focus is predominantly with the largest section that stretches across the Tanzania-Kenya border, the Kisongo, with some reference to the Matapato and the Kaputei sections in Kenya.

Much has changed for Maasai over the past century, including land loss (to farms, protected areas), livelihood diversification, formal education and religious conversion (Kituyi, 1990; Hodgson, 2001; McCabe, 2003). But the agegrade system still forms the foundation of Maasai social structure (Spencer, 2003; Goldman, 2006) in a way that is essential to understanding Maasai lion hunting. While there are slight differences across sections the main aspects of the system are similar. A new age-set is started every 10-15 years, with boys initiated (through circumcision) as young men or ilmurran (pl.; olmurrani, sing., translated into English as 'warriors'). The initiated boys become part of an organized age-set, to which they belong for the remainder of their lives, proceeding together to become junior then senior elders. The 'warrior' age-grade lasts approximately 20 years for each age-set, providing for a parallel overlap with at least one and sometimes two age-sets of ilmurran. Historically, this provided a standing army to protect the community from threats to people and livestock (Waller, 1979: 172) and ensure that younger ilmurran learn from their older cohorts.

Today it remains the duty of ilmurran to protect the community and cattle from raiding neighbouring groups, predators and the impacts of drought. They continue to learn from elders and senior cohorts, particularly regarding hunting lions (olamayio). Part of the duties of ilmurran is to know how to hunt lions. For this reason research on lion hunting has focused almost exclusively on attitudes and behaviours of ilmurran. However, the actions of ilmurran are monitored and mediated by their elders, mothers, girlfriends and wives. 
Across both sites the Maasai word for any organized hunt of a dangerous animal (usually lions but also buffalo, elephant and rhinos) is olamayio (see also Mol, 1996: 24). Olkiyioi is the Maasai word for war cry. When faced with an emergency ilmurran rally each other, issuing an olkiyioi by blowing a ceremonial kudu horn, delivering the message by foot, or today with the use of mobile phones. An olkiyioi can be called in response to any threat. If an olkiyioi is called because of a lion attack on livestock then the ilmurran go on an olamayio. For the Matapato and Kaputei of Kenya the understanding is the same, with the word empikas (meaning a delegation of ilmurran going on a raid or a hunt) used interchangeably with olamayio. Therefore, while Maasai may at times interchange the terminology there is general agreement across sites that all lion hunts (with a spear) are olamayio.

An olamayio is an organized group hunt conducted by ilmurran, although elders often participate when there has been an attack on livestock. The men track the lion, surround it and attack it with spears. Olamayio also refers to the celebration that follows successful hunts, when ilmurran are credited for the kill, and only when none of the participants are injured. With Kisongo, the first two ilmurran to spear the lion are celebrated, with the first one who drew blood referred to as the owner of the lion (olopeny olowaru). With the Matapato and Kaputei in Kenya there are two owners: the first one to grab hold of the tail of the lion while it is still alive, and the first to spear. In some sections the owner of the lion receives a new name (enkarna olowaru) in recognition of his achievement. However, in all cases it is the age-set as a whole more than the individual that is credited with the kill. The lion tail and front paws are taken as trophies and carried by ilmurran on the tips of their spears throughout the olamayio celebration, which involves the entire community (men, women, elders, ilmurran and young girls). The hunt is celebrated at nine bomas (Maasai settlements), or eight in the case of a lioness. Killing lions by other means, such as with poison or a gun, is considered cowardly and thus not an olamayio; there is no celebration. Killings with poison occur in Kenya and with poison and guns in certain parts of Tanzania (Simanjiro) but not in the area we studied.

Maasai have also killed lions and other charismatic species as political protest against what they perceived as unfair conservation policies. In 1971 Maasai killed large numbers of lions, leopard cubs, hyenas, rhinos and elephants around Amboseli National Park in reaction to the loss of land and resources to the Park (Western, 1982). In 2003, outside Nairobi National Park, Maasai killed lions allegedly in an effort to get the attention of Kenya Wildlife Services to address increasing predation on their livestock by lions after a severe drought (Itano, 2003; interview with community leader by MJG, 2005). In Tanzania, although such high profile political killing of wildlife is less common, lion hunting patterns in particular places can be seen as directly related to local conservation politics. Maasai in both countries have been heavily affected by conservation policies, including the loss of grazing land, permanent water sources and dry season grazing reserves through the creation of protected areas (Homewood \& Rodgers, 1991; Igoe, 2004; Goldman, 2011) and the negative impacts of wildlifelivestock and wildlife-people interactions (Homewood \& Rodgers, 1991; Lichtenfeld, 2005). Despite playing a large role in the tourism industry in both countries (Bruner \& Kirshenblatt-Gimblett, 1994), and sometimes receiving financial benefits from tourism, most Maasai communities remain excluded from decision-making processes regarding conservation in and adjacent to their lands.

\section{Study area}

In Kenya research was conducted in the $8,500 \mathrm{~km}^{2}$ Greater Amboseli Ecosystem (Fig. 1; BurnSilver et al., 2008) within three group ranches: Osilalei, Olgulului-Lolarrash and Imbirikani. This area is home to the largest free-ranging contiguous lion population in the region (Maclennan et al., 2009). Research spanned two Maasai sections, Kisongo and Matapato, in southern Kajiado District, Rift Valley Province. In the Matapato study site, in Osilalei, households combine pastoralism with rain-fed cultivation on private ranches. The two other group ranches belong to the Kisongo section. In Olgulului-Lolarrash group ranch research took place on a ridge north of Amboseli National Park, where extensive livestock herding is the main land use. Research in Imbirikani group ranch was conducted in the surrounding areas of two small towns (Kalesirua and Namelok). Local households are predominantly agropastoralists, combining livestock herding and irrigated horticulture (beans, onions, tomatoes) in nearby drained swamps. There are no tourism and conservation initiatives in Osilalei. In Imbirikani and Olgulului-Lolarrash group ranches several households receive some income from businesses and employment related to tourism and conservation. Imbirikani group ranch is the locus of several conservation efforts specifically targeting Maasai-lion interactions and lion hunting. One, a predator compensation fund and programme, financially compensates herders for depredation losses (Maclennan et al., 2009). Another programme innovatively employs local ilmurran as lion guardians, involving them in monitoring lion movements, educating the communities, deterring lion hunts and improving husbandry techniques (Frank et al., 2007). Additional interviews and ethnographic data collection took place in the Kaputei Maasai section in the Kitengela Community, adjacent to Nairobi National Park.

In Tanzania research was conducted in the TarangireManyara Ecosystem $\left(20,000-35,000 \mathrm{~km}^{2}\right)$, in two Maasai 


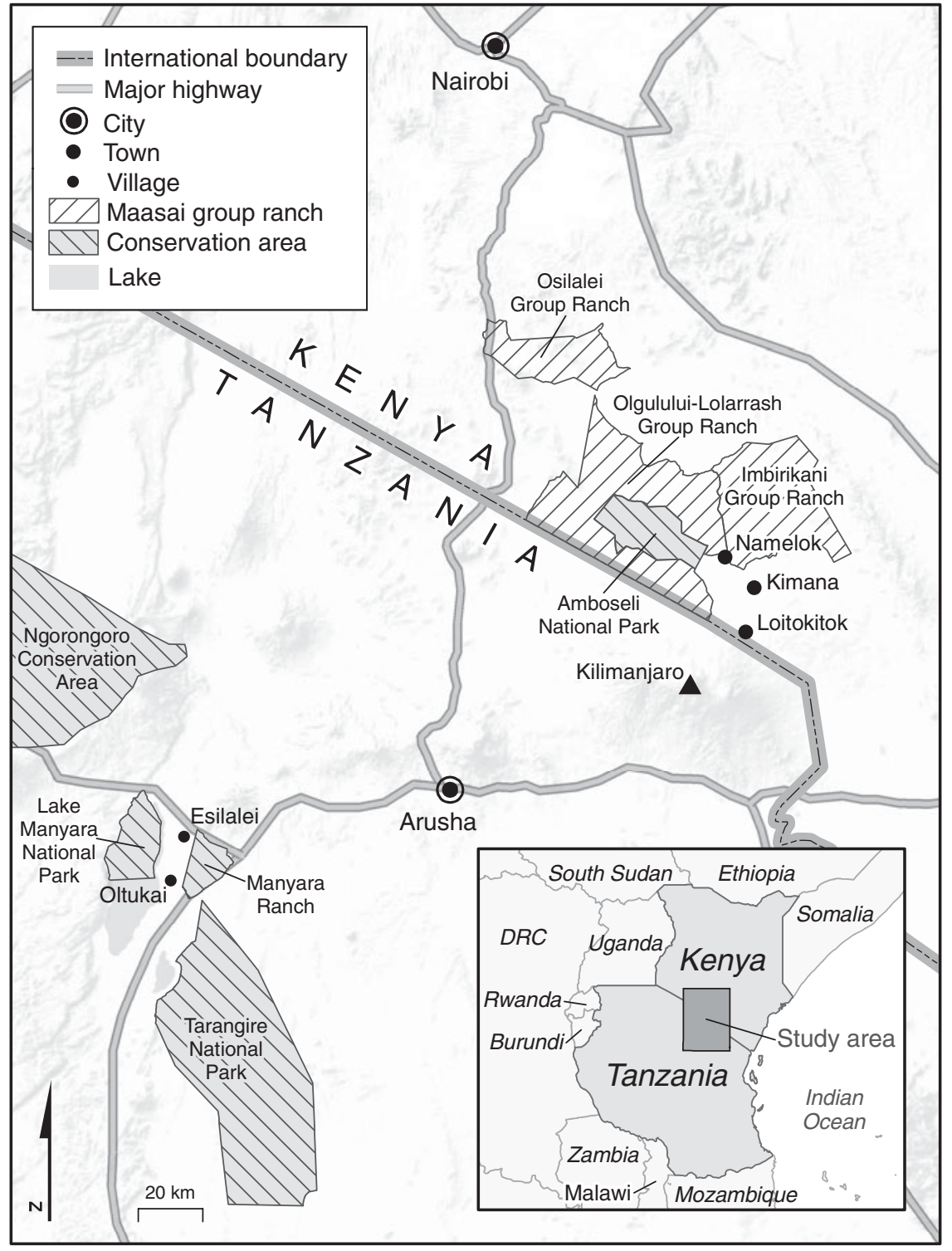

FIg. 1 The study area: the Greater Amboseli Ecosystem in Kenya and the Tarangire-Manyara Ecosystem in Tanzania. The rectangle on the inset indicates the location of the main map on the Kenya-Tanzania border. villages, Oltukai and Esilalei, located within a wildlife corridor area between Tarangire and Lake Manyara National Parks (Goldman, 2009). Both villages border Lake Manyara and a conservation area formed in 2002, Manyara Ranch. Pastoralism is the primary livelihood, practised together with small-scale rain-fed cultivation (mostly maize and beans), and supplemented with wage labour (as guards in the city, game scouts or herders in the neighbouring Manyara Ranch) and or small business ventures (cattle, crops, gemstone trading) by at least one member of the household (Goldman, 2006). This area has one of the world's greatest densities of animal biomass (Sumba et al., 2005) and is home to the fourth largest lion population in Tanzania (Kissui, 2008).

Both study areas are savannah-steppe environments within the semi-arid climatic zone (Pratt \& Gwynne, 1977). Rainfall is spatially and temporally variable, with averages of
$<650 \mathrm{~mm} \mathrm{year}^{-1}$ and concentrated in NovemberDecember and March-May (Prins \& Loth, 1988; Altmann et al., 2002). In the dry season wildlife cluster around permanent water sources inside national parks. During the wet season wild herbivores migrate into rangelands inhabited by Maasai, and predators follow.

\section{Methods}

We used semi-structured interviews to elicit specific information on local understandings of lion hunting in Kenya (2002-2004) and Tanzania (2008). These data were augmented by in-depth, unstructured, ethnographic data collected at both sites in 2002-2004, 2005, and in Tanzania again in 2007 and 2008.

In Kenya JRP moved between three different communities, obtaining $>200$ hours of ethnographic observations. 
In Tanzania MJG resided full-time in the study area and observed regular meetings between communities and local conservation agencies, obtaining $>300$ hours of ethnographic data. She also conducted additional ethnographic data collection in Amboseli and Kitengela in Kenya (2005). In both countries we collected ethnographic data regarding people-lion relations, lion hunting and feelings about local conservation interventions (through participant observation, informal conversations, group and key-informant interviews, stories, and discussions after lion hunts).

We used semi-structured interviews to ask similar questions in both countries about local perceptions of lion hunting (i.e. what causes lions to be hunted?) and how important lion hunting is nowadays. Interviews were conducted in Maa (Kenya) and in Swahili and Maa (Tanzania), translated to English, recorded and transcribed with the help of local assistants.

In Kenya we randomly selected 32 households at each site and systematically interviewed two individuals in each household: the household head, most frequently a married male, and one dependent ( $\mathrm{n}=96$; wife, children, and others dependent on the household head for food). The final sample $(n=191)$ includes $57.1 \%$ men (91 junior and senior elders, 11 ilmurran, and eight boys) and $42.9 \%$ women ( 76 adults, five girls). Ilmurran are underrepresented as they were frequently unavailable because of herding and schooling duties. Our Kenyan data thus mostly reflects understandings and perceptions of elders and adult married women.

In Tanzania, in April 2008, we used semi-structured interviews $(\mathrm{n}=55)$ to repeat questions previously asked in Kenya regarding lion hunting. To avoid under-representation of ilmurran we followed a stratified sampling strategy and randomly selected individuals within three groups: ilmurran $(\mathrm{n}=17)$, elders $(\mathrm{n}=21)$ and women $(\mathrm{n}=17)$ across both villages.

The question about the reasons for participating in lion hunts was open-ended, with informants allowed to name several reasons. We classified answers into different categories (the same for both sites), and quantified the frequency of each type of answer. Consistency in the allocation of responses to the different categories was ensured by cross-checking data and translations across sites. We present verbatim quotes from informants to support and illustrate our analysis. Within the text verbatim terms and concepts from informants are indicated with quotation marks.

\section{Why Maasai hunt lions}

Maasai hunt lions for multiple overlapping reasons, some related to direct predation on livestock and some not. We discuss these reasons by study site.
Kenya

In Kenya the most common response (76\%) for why a lion was hunted was related to achieving and reinforcing the role of ilmurran in society. Specific responses included a way for young men to obtain prestige (29\%), a test of one's bravery (22\%), the wish to obtain the prestigious 'lion name' (18\%) and winning the attention of girls ( $7 \%)$. These explanations overlapped, with several informants mentioning more than one. Lion hunts were discussed simultaneously as an interview' or 'exam' of ilmurran skills, and as bringing status to the entire age-set. Other people mentioned the hunt as the opportunity to practice 'warriorhood' in general and to maintain Maasai culture (10\%), for fun and enjoyment (4\%) and to practice spearing skills (2\%).

The overlap of these reasons and the value of olamayio in meeting expectations for ilmurran is illustrated in the following quote from an elder in Kenya:

[Olamayio is important] because the olmurrani who owns the lion will celebrate and will be liked by isiankikin [young girlfriends, wives] and will get a new name. So he looks like he is the one who killed the lion alone when in fact there were so many other ilmurran who helped in killing it. When thirty ilmurran go on olamayio the one who first touches the lion with his spear, he is the owner of the lion. Even if the lion is going to injure you, you don't mind! This is why we go for the 'interview': to show who is the bravest, or the strongest or the fastest olmurrani and who isn't. So this one sets the expectations for the whole age-set (Kisongo junior elder, Imbirikani group ranch, 2002).

Only $14 \%$ of Kenyan informants mentioned livestock predation as a reason for killing lions, whereas $18 \%$ mentioned killing lions as a way to prevent them from preying on livestock. This includes responses explaining the purpose of olamayio as: to keep aggressive wild animals away from people and cows; to 'save cows,' and to keep lions from becoming habituated to killing domestic animals. A Kenyan Kisongo senior elder (Olgulului-Lolarrash group ranch, 2003) explained that, in the event of a lion killing one of his cows '[he] would gather the ilmurran, follow the lion and make sure we kill it so it never comes back. Now that killing wild animals is forbidden,' however, 'that lion will just go and may be the next day it will eat another cow.'

In the Amboseli area Maasai perceive tensions between people and wildlife as having increased as a result of the prohibition to kill wildlife and the creation of 'places only for wildlife' (i.e. protected areas), which is best expressed in the following two quotes:

Ilmurran used to chase [wildlife] and killed the ones causing problems, so these animals feared people. Now, even ilmurran have decided not to chase and not to kill them. So animals have become more aggressive.' (Kisongo senior elder, Olgulului-Lolarrash group ranch, 2003).

Because they are not being killed any more the problem [of wildlife attacking people] has increased: we are not used to each other any 
more. So, the moment we meet, we are enemies. Even before, the lion didn't eat people that much [...]. It was believed that if you were eaten by a lion for nothing it meant that you were cursed (Kisongo elder woman, Imbirikani group ranch, 2002).

Many informants argued that it was 'the work of the ilmurran' to keep wild animals fearful of and away from people and livestock. This illustrates the overlapping reasons Maasai hunt lions: as the work of the ilmurran, to keep up expectations that they are capable of this and other responsibilities, and to maintain a safe environment for people and livestock. Yet at the same time, elders and women often try to dissuade ilmurran from going on olamayio (it can result in human injury or death), or from killing too many lions or other wild animals during a hunt, which is considered a sin. Going on olamayio in Kenya may now lead to the arrest of those who participate. According to one elder, olamayio is now happening less frequently, and 'only if a cow was injured or killed by wildlife. ... Before, they would just go even if a cow was not eaten. Now they fear that they may be arrested by the government' (Kisongo senior elder, Imbirikani group ranch, 2002). Yet another Kisongo junior elder (Imbirikani group ranch, 2002) suggested that hunting continues secretly, 'yes [olamayio is occurring] less and very secretly because the government is against killing wildlife.' In addition to being illegal, for some ilmurran lion hunting does not fit with their changing lifestyles. As one Kenyan Kisongo woman remarked (Imbirikani group ranch, 2002), 'yes, [olamayio is happening but] less because many ilmurran have now gone to school and some to church and they are busy.'

With olamayio illegal in Kenya, people have begun to use poison to kill lions following predation on livestock. This occurs in secret and is not celebrated, being considered cowardly and shameful. Restrictions on practising olamayio were seen as directly linked to the power of the conservation sector and the government (often conflating the two). As a Kisongo junior elder from Olgulului-Lolarrash group ranch (2003) explained, olamayio is still happening but 'very little,' because, "no elder will allow the ilmurran to come and celebrate at his boma and enjoy olamayio, because of KWS [Kenyan Wildlife Service] rules.' Additional restrictions on olamayio in Imbirikani group ranch were enforced through the local predator compensation programme, which makes compensation to individual herders who lost cattle to predators conditional on the absence of any lion hunting in a certain area for a certain period (Maclennan et al., 2009). This programme potentially influenced 'lion hunt politics' in the area as well. In one revealing episode, JRP came across an olamayio of 11 ilmurran, returning from an unsuccessful hunt, which was carried out on the day of the launching of the compensation programme. The participants justified that hunt as the expression of their disagreement with the compensation flat rate. Conservation workers also reported a series of hunts (of lion and other wildlife) in a neighbouring group ranch, rumoured to be orchestrated as an attempt to demand a compensation programme (S. Maclennan, Kilimanjaro Lion Conservation Project, pers. comm., 5 February 2005). These instances suggest that uneasy relationships with conservation goals and initiatives and power struggles over the management and profits related to wildlife can lead to a different reason for killing lions: as a political statement. Such protests are not new for Maasai in Kenya. In 2003 Kaputei Maasai living adjacent to Nairobi National Park killed lions in protest when their requests for support and dialogue with KWS were not met. According to local Maasai, lions were preying on sick and recovering cattle after a severe drought. They had asked KWS to intervene, and received no response. One of the Maasai leaders of the group that led the protest explained, 'We were killing lions because of the cruelty of the government. Not because the lions erred but because the government refused to help' (interview, 2008).

\section{Tanzania}

In Tanzania the most frequent explanation for why lions were hunted was livestock depredation, mentioned by $95 \%$ of informants. As one Tanzanian olmurrani explained: 'We call olkiyioi (alarm cry) after the lion attacks livestock and then we go on olamayio' (interview, 2008). However, ilmurran do not always wait until a lion attacks livestock but often kill lions perceived as preparing to attack, and to ensure that lions stay away from people and livestock. Such hunts were mentioned by $27 \%$ of Tanzanian informants and include those who referred to killing lions in the wet season, when carnivores follow migratory wild herbivores into village lands (Kissui, 2008) and are seen as a threat. Ilmurran are on the lookout during this time and if they hear a lion in the area for a few days, will hunt it. Some researchers have suggested that the rise of lion hunting in the wet season is because ilmurran are idle at this time, with nothing better to do (see Frank et al., 2006 for Kenya). Yet in the wet season lions follow wildebeest and zebra that come near Maasai settlements (for protection against lions, according to Maasai) a behaviour also described by Reid et al. (2003) and Goldman (2006).

The protective nature of hunting lions at this time was explained by an Esilalei olmurrani (2008):

Soon after we see the lion near our homes we maybe hear it in the night. Tomorrow morning we start following it. [So it does not always attack livestock first?] We can follow him before he attacks the livestock. We have to protect our cows before [the lion] attacks.

Explaining why lions were hunted after predation on livestock a senior elder from Esilalei explained (2008):

We know the character of lions. If a lion eats cattle, it will keep eating cattle until you kill it. It will run to eat cattle until you kill it or you move. But the ilmurran say, 'don't move, let's go and kill that lion.' 
A senior elder from Oltukai explained that when he was an olmurrani, he 'killed a lion so it would no longer kill cattle.' When asked if ilmurran could be prevented from killing lions today if monetary compensation for the lost cattle was provided he emphasized the need to kill the responsible lion (2008):

We cannot agree [to compensation] because we do not have cattle to be killed every day! We must go and kill that lion because our payment is to kill that lion today. If they pay money today, then tomorrow, they will pay every day because the lion will keep coming back to eat cattle until all the cattle are gone. And then what will we do with the money?

The same elder further illustrated why financial compensation did not make sense, did not stop lions from killing cattle and would not stop ilmurran from killing lions. His response suggests the emotional dimension of hunting a lion that has killed one's cow (2008):

My son's boma had two cattle killed and one olmurrani hurt [by a lion]. I cried, so the lion must cry. [Let's say] another lion then comes to the settlement another day. The government says 'don't go [kill the lion] and we will pay [compensation]'. But we cannot do it. We cannot stop the ilmurran because we already lost our cattle and this loss hurts deep in our soul [roho].

A junior elder and member of the village government in Oltukai revealed that an American tour operator approached the village about starting a compensation project to pay families that lost cattle to lions in exchange for allowing the lion to live. 'But the people refused,' explained the elder. 'They complained that the lions would learn that it is all right to eat cattle. And so for now, you will pay, but what happens when you and your organization leave? Who will pay then? And the lions will have learned already to eat cattle. No. We refused' (2008).

These statements suggest the limitations of monetary compensation programmes designed to prevent 'retaliatory' hunts. Our informants suggest that post-predation hunts also address the emotional loss felt by herders, while eliminating an individual lion and preventing it from killing cattle again.

Lion hunting seems to have lost some of its prestige and reward in winning girlfriends for ilmurran in this area, with only $16 \%$ of informants naming pride/prestige as a reason for killing lions. This sentiment was expressed in a group interview (six ilmurran, 2008), at which one man stated (and others agreed) that, 'today, for an olmurrani, having money and cattle is more important for obtaining status than having killed a lion.' However, several individuals spoke about the continued importance of olamayio for 'warriorhood' ( $13 \%$ ), with $4 \%$ naming the start of a new ageset of ilmurran as a reason for lion hunts and $9 \%$ stating that lion hunting was part of 'the work of the ilmurran.' When a new age-set is initiated the older ilmurran teach the young ones how to hunt, leading to an increase in lion hunting that continues for a few years after the older ilmurran graduate, leaving the younger, new ilmurran on their own (as was the case at the time of this research). At this time the new ilmurran feel they need to prove themselves as proper warriors, capable of protecting the community's cattle. As one Tanzanian olmurrani remarked (2008), 'We just do it [hunt lions] because we were given responsibility of the cattle.'

Today, because of changes occurring within Maasai society and the tolerance of killing lions after predation in Tanzania, olamayio is said to occur primarily after predation on livestock. However, this does not diminish the importance of olamayio as a socio-cultural practice. When we asked if olamayio was still important today, $96 \%$ of informants said yes. When olamayio occurs after a predation incident the celebration occurs as usual. Forbidding this to occur can have negative repercussions, as discussed below.

\section{Are local conservation politics influencing} Maasai lion hunting practices?

Ethnographic work in Manyara Ranch over a 6-year period provides added insight into the ways in which changes related to conservation interventions and age-set dynamics can affect lion hunting. Our description comes from ethnographic observation, targeted interviews and informal discussions (see also Goldman, 2011).

Manyara Ranch was created as a conservation trust in 2001 from a former state run cattle ranch. When it was on sale Maasai in Oltukai and Esilalei villages claimed historical ownership and asked for the land to be returned to them. Meanwhile, the African Wildlife Foundation lobbied for and obtained the area to be run by the Tanzanian Land Conservation Trust, chaired by a local member of parliament. The trust was to run the Ranch as a multiple-use conservation area combining ranch cattle, wildlife conservation and dry season grazing by Maasai; a steering committee was established to facilitate Maasai participation in management. As a conservation area, lion hunting was prohibited inside the Ranch. In 2002 feelings about Manyara Ranch in both villages were positive. People explained that Manyara Ranch was 'theirs'; they had allowed African Wildlife Foundation to manage the wildlife, with hope that benefits from tourism would reach their communities. During this time village elders and even some senior ilmurran kept the ilmurran as a group from killing lions, even after predation on livestock. In 2002 there were two sets of ilmurran, and many of the senior cohort were members of the Manyara Ranch steering committee.

As Manyara Ranch became more established, a new manager was hired and new rules were put in place. Access to grazing became increasingly restricted by Manyara Ranch management (to prevent overgrazing), and Maasai active participation in management of the area (including 
decisions regarding grazing) became extremely limited. Villagers, and ilmurran in particular, felt alienated from the conservation area and betrayed by their leaders (and the ilmurran by the elders). As feelings about Manyara Ranch changed, so did lion hunting patterns.

During 2002-2004 there were five incidences of lion depredation on livestock after which the elders and some senior ilmurran prevented an olamayio. In the first three cases, elders stopped ilmurran from calling an olkiyioi. In another case ilmurran went on olamayio and the elder whose cattle were killed notified the Ranch manager, to intervene and stop them. In the final case, the ilmurran called olkiyioi and began to track the lion when the elder whose cattle were killed (also a member of the steering committee) called the manager to track down the ilmurran and pleaded with them to give up the hunt, which they did. No compensation for any of the losses occurred nor was there communication from Manyara Ranch about how such instances would be addressed in the future to compensate for Maasai losses. One elder vented his frustrations on the issue in response to the general question if you were able to advise on management of the Ranch, what would you say?'

Yesterday three of my cows [donkeys] were eaten. And me, I have a gun. And my ilmurran, they can fight a lion. But how will I advise when Manyara Ranch says I am unable to do anything. My cattle die and they do not kill that lion! They prohibit us from entering the Ranch and wildlife from the Ranch leave and eat our cattle? They say that this place is ours? And this is what happens? (Senior elder, Esilalei, 2003)

By 2005 restrictions on grazing cattle in Manyara Ranch had increased, and many ilmurran felt alienated from its management and deprived of what had been promised to them, while wildlife numbers (including lions) were seen as increasing (Goldman, 2006). The senior ilmurran had graduated to elderhood in 2003 and could no longer control the junior ilmurran who were now 'in charge of the cattle' and ready to prove their capabilities to protect their communities and property. Lion hunting increased in frequency and severity and was no longer discouraged by the elders. In 2005 two lions were killed by ilmurran from Oltukai, after predation on livestock. In December 2006 six lions were killed in one hunt in a neighbouring village, with ilmurran from Oltukai and Esilalei participating. The hunt was called after depredation on cattle, and when the entire pride was caught all six lions were killed. An elder suggested that the killing of so many lions at once was unusual and done to make a political statement: to express anger at getting nothing from the Ranch while lion numbers were increasing. Another elder shook his head in dismay saying such actions were not normal or acceptable (i.e. killing the whole pride). In March-May 2007 five lions were killed in reaction to a total of 27 cattle being killed by lions in 1 month. In 2008 ilmurran killed six lions. On one occasion, ilmurran entered the Ranch to kill a lion that had preyed on livestock. On their way home with the tail and paws for the olamayio celebration they were stopped by game scouts, who confiscated the trophies and stopped the celebration.

This particular event pushed the tensions between villagers and Manyara Ranch into an open conflict. Ilmurran complained that the hunt had been legitimate because predation had occurred. They felt denied their legitimate rights to hunt the lion and celebrate the successful hunt. Although all lion hunting without a permit is illegal, much of the hunting by Maasai is tolerated. In fact, Manyara Ranch had put in place an unofficial policy that ilmurran were to notify management (by phone) when going on olamayio. The management would then try to dissuade the ilmurran but would not use force. However, this time ilmurran killed a lion inside Manyara Ranch, and this was difficult to ignore. Yet, for ilmurran, the lion had left the Manyara Ranch boundaries to prey on their livestock, and they did what they saw was their responsibility: to follow the lion and hunt it.

When denied their right to celebrate the hunt, the ilmurran retaliated. They began pursuing lion hunts whenever possible. During this time (May 2008) several ilmurran explained that they used to follow Manyara Ranch rules and not hunt lions unless livestock were killed and then only in consultation with elders and after reporting to Manyara Ranch. This was an understanding that all had agreed. Now they asked: 'why should we respect the rules when Manyara Ranch does not respect us?' According to several informants (eight ilmurran and elders, 2008) in a meeting held by Manyara Ranch management in May 2008, ilmurran openly threatened to kill as many lions as they could, regardless of where the lion was and even if no cattle were killed. If they caught 10 lions in front of the Manager's house, they threatened to kill all 10. The ilmurran felt betrayed by Manyara Ranch and by their elders for having agreed to the conservation area in the first place. Elders lost their power to dissuade ilmurran from hunting and many saw no reason to do so. As one elder stated (2008), 'we have no reason to follow the rules. We no longer have any confidence/trust (imani) in Manyara Ranch.' The result, another elder recalled, was that Manyara Ranch could no longer be taken seriously as a conservation area, because those entrusted with its conservation were not trusted and the partner villages were killing lions.

\section{Discussion}

In both Tanzania and Kenya lion hunting fulfils several different functions, including: to reaffirm the protective role of ilmurran in society, to help select brave leaders among the ilmurran, for individual ilmurran to gain prestige, to eliminate lions that prey on livestock, and to keep lions from becoming habituated to people and livestock. These 
different reasons are not mutually exclusive but overlap and reinforce each other.

In Tanzania the most common reason given for killing lions was related to predation on livestock, yet such hunts also fulfilled a desire to win individual recognition and show the capacity of the age-set as a whole. In Kenya prestige was the most common reason given for hunting lions but elders acknowledged that olamayio mostly happens today when there is predation on cattle.

The overlapping reasons reported for hunting lions illustrate the limitations of the dichotomous explanation of Maasai lion hunting as either a cultural manhood ritual or a retaliatory act. Such a categorical system misses the important nuance and overlap of rationales for lion hunting, and forces Maasai knowledge, behaviour and reasoning into Western categorical constructs. Maasai see the training of ilmurran to hunt lions as an important social act, which is linked to the process of social learning by lions and ilmurran of the dangerous character of the other, and keeps lions from becoming habituated to preying on livestock.

Maasai believe that killing lions that attack livestock keeps other lions from doing so. Research in Kenya (Woodroffe \& Frank, 2005), although not supporting such a hypothesis, suggests that lion predation on livestock is a rare behaviour and that selective hunting of stock-killing lions can help to avoid the spread of 'such damaging behaviour through the population.' Although some may take issue with Maasai anthropomorphizing of lions, for Maasai this is an important component of their relationship with wildlife. Maasai also perceive lions as capable of positive behaviours, such as protecting women and children, and have stories of rewarding such behaviours accordingly (Goldman et al., 2010). This process of humanizing relations with animals may contrast with Western scientific ways of knowing and managing wildlife but has been well documented in the literature on indigenous people (Goldman, 2007; Nadasdy, 2007; Watson \& Huntington, 2008), and can offer important insights for wildlife conservation (Nadasdy, 2003).

Lion hunting patterns by Maasai are not static. They fluctuate with social transitions and conservation politics. People in both areas acknowledged that ilmurran are changing and that lion hunting as an important way of gaining prestige is also declining. Informants spoke of going on olamayio today only when necessary: when lions attack cattle. Yet lion hunting is still seen as the responsibility and privilege of ilmurran. In both sites, informants spoke about olamayio with pride and as a vital part of Maasai culture: important for the 'owners' of the lion, the group that went on the hunt and the community at large. Participatory conservation interventions that respect Maasai knowledge and promote full engagement with management processes are likely to have better success in persuading Maasai to change or moderate such behaviours themselves.
Lichtenfeld (2005) suggested that Maasai-lion relations are connected to the degree of control, or lack thereof, that Maasai have over conservation-related decision making processes that affect their livelihoods. The case study with Manyara Ranch showed that elders could exert pressure on ilmurran to refrain from killing a lion, even after predation, when they felt involved in a particular conservation endeavour and attached to potential benefits from it. Maasai residents in Oltukai and Esilalei wanted to participate in Manyara Ranch management and benefit from tourism and grazing for their cattle. Increased alienation from decision making, restrictions on grazing and little to no benefits from wildlife conservation tourism despite increased costs (of predation and crop raiding), led to antagonism with the conservation area and a rise in lion hunting.

This was also a time of changing age-set dynamics and a new group of ilmurran could have been determined to show their capacity as the 'soldiers of society.' However the conflict described here sparked protests by both elders and ilmurran, whose words showed that they were not retaliating against lions as much as they were reacting to a lack of control over wildlife and a loss of faith, trust and communication with the conservation area. Similar sentiments can be gleaned from the protest killings in Kitengela, where Maasai claimed they were not angry at lions as much as they were angry at KWS. There is a history of such protest killings in Kenya (Western, 1982), reflecting the complex politics involved in conservation decision-making.

Lion conservation projects rarely address such complex politics. Even the more innovative approaches to lion conservation being employed in Kenya (e.g. Lion Guardians), which promote community participation, work under the assumption that Maasai need to be taught how and why to conserve lions, so that they do not hunt them to extinction. Yet research shows that Maasai want lions around in the future because of their special role in Maasai culture and identity (Goldman et al., 2010). Conservation interventions could start by highlighting such positive aspects of Maasai-lion relations. Researchers and conservation organizations could work collaboratively to better understand Maasai lion hunting practices and how such practices can be curtailed if necessary in ways that respect Maasai cultural and socio-economic needs while also protecting lion populations. Recent literature on human dimensions of wildlife suggests that this sort of participatory approach to conservation interventions is essential to reduce humanwildlife conflict and protect the future of wildlife populations (Treves et al., 2006, 2009).

This paper contributes to a growing literature on human-carnivore relations by adding a focus on conservation politics, within an ethnographic perspective. Ethnography complements existing quantitative work by providing an in-depth picture based on local knowledge and understanding. Deep ethnographic engagements with 
communities are not often part of conservation projects or research on lions but address the need for cross-disciplinary research for improved conservation (Brosius, 2006; Redford, 2011).

\section{References}

Altmann, J., Alberts, S.C., Altmann, S.A. \& Roy, S.B. (2002) Dramatic change in local climate patterns in the Amboseli basin, Kenya. African Journal of Ecology, 40, 248.

Bauer, H., Nowell, K. \& Packer, C. (2008) Panthera leo. In IUCN Red List of Threatened Species v. 2012.1. Http://www.iucnredlist.org [accessed 11 October 2012].

Brosius, J.P. (2006) Common ground between anthropology and conservation biology. Conservation Biology, 20, 683-685.

Bruner, E.M. \& Kirshenblatt-Gimblett, B. (1994) Maasai on the lawn: tourist realism in East Africa. Cultural Anthropology, 9, 435-470.

BurnSilver, S.B., Worden, J. \& Boone, R.B. (2008) Processes of fragmentation in the amboseli ecosystem, Southern Kajiado District, Kenya. In Fragmentation in Semi-arid and Arid Landscapes: Consequences for Human and Natural Systems (eds K.A. Galvin, R. Reid, R.H. Behnke \& N.T. Hobbs), pp. 225-253. Springer, Dordrecht, The Netherlands.

CRILlY, R. (2006) Survival of lions threatened by the tribal delinquents who kill for pride; Mbirikani Group Ranch, Southern Kenya. The Times. Http://wildland-network.org/news/news2006/ wn_news_mayo6.htm [accessed 30 May 2008].

FRANK, L. (2006) Living with Lions: Laikipia Predator Project Kilimanjaro Lion Conservation Project. Annual Report. Museum of Vertebrate Zoology, University of California, Berkeley, USA.

Frank, L., Cotterill, A., Dolrenry, S., Ekwanga, S., HazZah, L., Howard, A. \& Maclennan, S. (2007) Living with Lions: Laikipia Predator Project. Annual Report. Kilimanjaro Lion Conservation Project, Living with Lions, Nairobi, Kenya.

Frank, L., Hemson, G., Kushnir, H. \& Packer, C. (2006) Lions, Conflict and Conservation in Eastern and Southern Africa: Background Paper Eastern and Southern African Lion Conservation Workshop. Johannesburg, South Africa.

Goldman, M. (2006) Sharing Pastures, Building Dialogues: Maasai and Wildlife Conservation in Northern Tanzania. $\mathrm{PhD}$ thesis. University of Wisconsin-Madison, Madison, USA.

Goldman, M. (2007) Tracking wildebeest, locating knowledge: Maasai and conservation biology understandings of wildebeest behavior in Northern Tanzania. Environment and Planning D: Society and Space, 25, 307-331.

Goldman, M. (2009) Constructing connectivity? Conservation corridors and conservation politics in East African rangelands. Annals of the Association of American Geographers, 99, 335-359.

Goldman, M. (2011) Strangers in their own land: Maasai and wildlife conservation in Northern Tanzania. Conservation and Society, 9 , 65-79.

Goldman, M., Roque de Pinho, J. \& Perry, J. (2010) Maintaining complex relations with large cats: Maasai and lions in Kenya and Tanzania. Human Dimensions of Wildlife, 15, $332-346$.

Hazzah, L. (2006) Living Among Lions (Panthera leo): Coexisting or Killing? Community Attitudes Towards Conservation Initiatives and the Motivations Behind Lion Killing in Kenyan Maasailand. MSc thesis. University of Wisconsin, Madison, USA.
Hazzah, L., Borgerhoff, M.M. \& Frank, L.G. (2009) Lions and warriors: social factors underlying declining African lion populations and the effect of incentive-based management in Kenya. Biological Conservation, 142, 2428-2437.

Hodgson, D.L. (2001) Once Intrepid Warrior: Gender, Ethnicity and the Cultural Poltics of Maasai Development. Indiana University Press, Bloomington, USA.

Homewood, K. \& Rodgers, A. (1991) Maasailand Ecology: Pastoralist Development and Wildlife Conservation in Ngorongoro, Tanzania. Cambridge University Press, New York, USA.

Igoe, J. (2004) Conservation and Globalization: A Study of National Parks and Indigenous Communities from East Africa to South Dakota. Wadsworth/Thompson Learning, Belmont, USA.

IKANDA, D. \& PACKER, C. (2008) Ritual vs retaliatory killing of African lions in the Ngorongoro Conservation Area, Tanzania. Endangered Species Research, 6, 67-74.

ItANO, N. (2003) Kenya's rural growth pits man against beast. The Christian Science Monitor, Kitengela. Http://www. csmonitor.com/2003/1104/po7so1-woaf.html [accessed 12 February 2013].

Kissui, B.M. (2008) Livestock predation by lions, leopards, spotted hyenas, and their vulnerability to retaliatory killing in the Maasai steppe, Tanzania. Animal Conservation, 11, 422-432.

Kituy , M. (1990) Becoming Kenyans: Socio-Economic Transformation of the Pastoral Maasai. Acts Press, Nairobi, Kenya.

Lichtenfeld, L.L. (2005) Our Shared Kingdom At Risk: Human-Lion Relationships in the 21st Century. PhD thesis, Yale University, New Haven, USA.

Maclennan, S. (2007) Lions, livestock and spears. Africa Geographic, September $2007,60-66$.

Maclennan, S.D., Groom, R.J., Macdonald, D.W. \& Frank, L.G. (2009) Evaluation of a compensation scheme to bring about pastoralist tolerance of lions. Biological Conservation, 142, 2419-2427.

McCAвE, J.T. (2003) Sustainability and livelihood diversification among the Maasai of northern Tanzania. Human Organization, 62, 100-111.

Mol, F. (1996) Maasai: Language and Culture. Mill Hill Missionary, Narok, Kenya.

Nadasdy, P. (2003) Hunters and Bureaucrats: Power, Knowledge and Aboriginal-State Relations in the Southwest Yukon. UBC Press, Vancouver, Canada.

NADASDy, P. (2007) The gift in the animal: the ontology of hunting and human-animal sociality. American Ethnologist, 34, $25-43$.

Ogada, M.O.R., Woodroffe, O.N.O. \& Frank, L.G. (2003) Limiting depredation by African carnivores: the role of livestock husbandry. Conservation Biology, 17, 1521-30.

Packer, C., Brink, H., Kissui, B.M., Maliti, H., Kushnir, H. \& CARo, T. (2010) Effect of trophy hunting on lion and leopard populations in Tanzania. Conservation Biology, 25, 142-153.

Patterson, B.D., Kasiki, S.M., Salempo, E. \& Kays, R.W. (2004) Livestock predation by lions (Panthera leo) and other carnivores on ranches neighboring Tsavo National Parks, Kenya. Biological Conservation, 119, 507-516.

Pratt, D.J. \& GWynne, M.D. (1977) Rangeland Management and Ecology in East Africa. Robert E. Krieger Publishing, Huntington, USA.

Prins, H.H.T. \& Loth, P.E. (1988) Rainfall patterns as background to plant phenology in northern Tanzania. Journal of Biogeography, $15,451-463$.

Redford, K.H. (2011) Misreading the conservation landscape. Oryx, $45,324-330$. 
Reid, R.S.M., Rainy, J., Oguto, R.L., Kruska, M., McCartney, M., Nyabenge, K. et al. (2003) People, wildlife and livestock in the Mara Ecosystem: the Mara Count 2002. In Report, Mara Count 2002. International Livestock Research Institute, Nairobi, Kenya.

RoACH, J. (2006) Lion killings spur fears of regional extinction in Kenya. National Geographic, 22 May 2006. Http://news. nationalgeographic.com/news/2006/05/060522-lions.html [accessed 12 February 2013].

Romañach, S.S., Lindsey, P.A. \& Woodroffe, R. (2007) Determinants of attitudes towards predators in central Kenya and suggestions for increasing tolerance in livestock dominated landscapes. Oryx, 41, 185-195.

Roque De Pinho, J. (2009) Staying Together: People-Wildlife Relationships in a Pastoral Society in Transition, Amboseli Ecosystem, Southern Kenya. $\mathrm{PhD}$ thesis. Colorado State University, Fort Collins, USA.

SpeAr, T. \& Waller, R. (eds) (1993) Being Maasai: Ethnicity and Identity in East Africa. Ohio University Press, Athens, Greece.

Spencer, P. (2003) Time, Space, and the Unknown: Maasai Configurations of Power and Providence. Routledge, New York, USA.

STEINHART, E.I. (1989) Hunters, poachers and gamekeepers: towards a social history of hunting in colonial Kenya. Journal of African History, 30, 247-264.

Sumba, D., Bergin, P. \& Jones, C. (2005) Land Conservation Trusts: A Case Study of Manyara Ranch. Unpublished Report. African Wildlife Foundation, Arusha, Tanzania.

Treves, A. \& Karanth, U. (2003) Human-carnivore conflict and perspectives on carnivore management worldwide. Conservation Biology, 17, 1491-1499.

Treves, A., Wallace, R.B., Naughton-Treves, L. \& Morales, A. (2006) Co-managing human-wildlife conflicts: a review. Human Dimensions of Wildlife, 11, 383-396.

Treves, A., Wallace, R.B. \& White, S. (2009) Participatory planning of interventions to mitigate human-wildlife conflicts. Conservation Biology, 23, 1577-1587.
URT (United Republic of Tanzania (1974) The Wildlife Conservation Act No. 12 of 1974. Government Printer, Dar es Salaam, Tanzania.

URT (United Republic of Tanzania) (2009) The Wildife Conservation Act. Government Printer, Dar es Salaam, Tanzania. W Aller, R. (1979) The Lords of East Africa: The Maasai in the Mid-Nineteenth Century, c. 1840-1885. PhD thesis, Cambridge University, Cambridge, UK.

Watson, A. \& Huntington, O.H. (2008) They're here-I can feel them: the epistemic spaces of Indigenous and Western Knowledges. Social and Cultural Geography, 9, 257-281.

Western, D. (1982) Patterns of depletion in a Kenya rhino population and the conservation implications. Biological Conservation, 24, $147-156$.

Woodroffe, R., Thirgood, S. \& Rabinowitz, A. (eds) (2005) People and Wildlife: Conflict or Coexistence? Cambridge University Press, Cambridge, UK.

Woodroffe, R. \& Frank, L.G. (2005) Lethal control of African lions (Panthera leo): local and regional population impacts. Animal Conservation, 8, 91-98.

\section{Biographical sketches}

MARA J. Goldman's work addresses the politics of knowledge and participation related to wildlife conservation and rangeland management, changing pastoral livelihoods and adaptation to climate change, and women's empowerment and governance issues among Maasai in Tanzania and Kenya. Joana Roque De Pinho is investigating human understandings of natural environments in rural communities in Kenya and Guinea-Bissau, and how these understandings shape human behaviours and conservation outcomes. She is currently engaged as an ethnographic film maker, using participatory photography and video to communicate local understandings of environmental issues in East Africa. Jennifer Perry is interested in human-wildlife conflict and how community-based conservation is affecting relationships between local communities and wildlife in Northern Tanzania. 